\title{
"... a certain amount of engineering involved": Constructing the public in participatory governance arrangements
}

\author{
Kathrin Braun and Susanne Schultz
}

This paper argues that it is time for public understanding of science to develop a critical inventory of the forms, formats and methods of public participation and their respective implications and ambiguities. It highlights the need for analysing not only the limitations and deficiencies of participatory arrangements but also their constructive dimension, in particular the construction of the subject of participation. Looking into participatory governance arrangements in the issue area of genetic testing in Germany and the UK the paper presents a typology of formats according to the way the respective public is constructed and identifies four major constructions of publics: the general public, the pure public, the affected public and the partisan public. Each of these enables certain speaking positions while foreclosing others. The study shows that the main purposes of participatory arrangements in this issue area are knowledge production and education rather than political deliberation and decision-making.

Keywords: construction of publics, genetic testing, participatory governance, public participation, speaking positions

\section{Introduction}

Discourses of public participation in science have become virtually hegemonic today. Since the 1990s there has been a participatory turn in science governance, indicated by a new language of openness, transparency, and deliberation as well as the proliferation of participatory arrangements and events. ${ }^{1}$ Particularly in the UK, but increasingly in other countries too, "public participation," "dialogue" or "public engagement" have become part of the active vocabulary of not only citizens, non-governmental organisations (NGOs), or social movement actors but also governments and institutionalised science. Today, as Sheila Jasanoff notes, it is "widely recognised that increased participation and interactive knowledge-making may improve accountability and lead to more credible assessments of science and technology" (Jasanoff, 2003: 243). ${ }^{2}$ While the breadth and depth of this participatory turn are a matter of dispute, it is safe to say that something has changed here. A growing body of literature suggests that scientific governance has indeed gone a long way from the old elitist expert model in which expert advice acted as the main authoritative source for policy-making. ${ }^{3}$ Yet, while 
it is easier to see what was left behind, it is not so clear where we are now with respect to public participation. The question that is increasingly discussed in public understanding of science (PUS) today is not so much whether there is a trend towards participation but what we are to make of it, how to assess it, how to understand the dynamics propelling it, how to systematise and interpret the different forms and trajectories it takes, what the benefits, pitfalls or unintended side-effects of these forms and trajectories are and for whom. This paper argues that it is time for PUS to develop a critical inventory of the forms, formats and methods of public participation and to examine and discuss their respective implications and ambiguities. Critical PUS research has already scrutinised the frameworks of a series of actual participatory exercises and exposed their limitations, deficits and constraints (for an overview see Felt and Wynne, 2007). What merits further investigation, we argue, are the constructive dimensions of public participation exercises. Critical PUS studies have done so already in that they examined the construction of policy problems and how they affect the range of possible recommendations and solutions. In particular, scholars have shown that issues relating to science and technology were oftentimes framed as matters of risk and safety only, at the expense of broader, social aspects (see for instance Irwin and Wynne, 1996; Levidow, 2007; Levidow and Carr, 1997; Wynne, 2002, 2005). What additionally deserves attention, we argue, are the processes of knowledge generation, education, and the construction of subjects in and through participatory exercises, the latter enabling certain speaking positions while restricting others. Highlighting the dimension of knowledge generation and subject construction, the article contributes to a more recent constructivist turn providing analysis of the productive, constructive dimension of participatory practices (Irwin, 2001, 2006; Irwin and Michael, 2003; Lezaun and Soneryd, 2007; Nowotny et al., 2004; Reardon, 2007).

Practices and arrangements of participation are both enabling and restricting at the same time. At issue, therefore, is not just the question whether we want to have more participation or less, but rather what the different forms and formats of participation actually do. The article will contribute to such an inventory and examine a specific aspect of what participatory arrangements do, namely construct the public that is supposed to participate.

It draws on some of the results of a case study that formed part of a multi-case research project on participatory governance in a European context in a series of contentious policy areas relating to issues of life (Gottweis and Braun, 2007; Gottweis et al., 2008). ${ }^{4}$ The research focused on the question of whether under conditions of uncertainty, contestation and institutional ambiguity classical modern forms of governing were challenged or modified by new forms of governance, in particular participatory forms of governance. The main focus was on the dynamics driving the co-evolution of issues, publics and institutional responses and the way in which participation was enacted in practices centring around these issues, ${ }^{5}$ taking these dynamics as the unit of analysis rather than doing a country-by-country comparison. ${ }^{6}$ This case study investigated how genetic testing has been framed as a matter of public concern, how frames have shifted over time, and which forms of public participation evolved in the context of these shifts in recent years in Germany and the UK. ${ }^{7}$ These two countries are interesting since they both went through major science controversies in the past decades, which, however, took different trajectories. In the UK, there is an agenda to institutionalise public participation and make it official government policy in many policy areas, including science and technology (Bauer et al., 2007; Burchell et al., 2009). Participation mainly takes the form of public consultations here, commissioned by government advisory bodies or authorities such as the Human Fertilisation and Embryology Authority (HFEA) or the Human Genetics Commission (HGC). Germany, in contrast, had a quite fundamental public debate on biomedicine around the years 1999-2001 (Braun, 2005; Herrmann, 2009) but only a few formal participatory experiments. ${ }^{8}$ In the context of the overall project and inspired by the 
concept of the "pure public," referring to the genetically modified organisms debate in the UK (Lezaun and Soneryd, 2007; Reynolds et al., 2007), we focused on the interplay between institutionalising public participation, constructing specific ideas of the public, and dealing with conflict and contestation. Since formal participatory arrangements have been relatively well established in the UK whereas Germany had comparatively few in this issue area, the material used here is mainly taken from the UK context. Hence, the article aims to highlight the variety of notions of "the public" that are, more or less consciously, enacted through such arrangements and to develop a typology that could be tested in further research (see Table 1 later) rather than drawing general correlations. We hold that on the basis of this material, we can discern four major types of constructions of the public which we labelled the general public, the pure public, the affected public and the partisan public.

\section{Rethinking participation}

Up to very recently, participation seemed to be a rather uncontested concept in PUS. In its most sophisticated vindication, civic participation is viewed as an opportunity for challenging a hidden amalgamation of science, power and vested interests and for giving voice to important socio-cultural and political questions that have been kept off the table by technocratic and elitist modes of governance (Fischer, 2000, 2005). While not all practitioners subscribe to this quite political understanding of participation, there has been a remarkable absence of theoretical and political controversy on its value in PUS. This is surprising, given that in political science, concepts such as participatory democracy or deliberative democracy ${ }^{9}$ have been subject to strong criticism. ${ }^{10}$ Elitist objections refer to citizens' lack of expertise concerning the issues at stake, as well as their susceptibility to group pressure and manipulation (Sartori, 1978). Feminist critics, on the other side, have pointed out that participatory and deliberative forms are based on eloquence and assertiveness and thus run the risk of further marginalising groups that are already marginal (Mansbridge, 1990; Sanders, 1997; Young, 2002). Adherents of a more adversarial understanding of politics, finally, have argued that the notion of achieving a consensus via rational debate is at best naïve and harmonistic and at worst banishes the dimension of conflictuality, antagonism and struggle from "the political""11 (Mouffe, 2006). While these debates have rarely been discussed in PUS, some of these points resonate in recent calls for a more sober, realistic investigation of the strengths, weaknesses, and ambivalences of participation. H. M. Collins and Robert Evans' emphasis on distinguishing between democratic participation and scientific expertise, for instance, and their insistence on the question of how far public participation should actually go evoke the classical warnings that participation tends to interfere with efficiency (Collins and Evans, 2002). From a different perspective, Gabriele Abels insists that serious issues of legitimacy would be at stake should processes of citizen participation actually replace procedures of representative democracy (Abels, 2007). More recently, Dominique Pestre (2008), in line with Chantal Mouffe on the issue of deliberative democracy, has argued that participation, dialogue and good governance form part of a new hegemonic ideology that, at best, distracts us from engaging the true decision-making agencies today, namely the market and non-accountable meta-powers, such as the World Bank. At worst they make us collaborate in the current transformation that undermines democratic accountability and replaces it with "infra-political practices - e.g. political correctness or superficial transparency" (Pestre, 2008: 105). "[T]here is such a thing as deliberate manipulation," Pestre (2008: 112 , original emphasis) warns us. This argument adds a new, sharp edge to the criticism of public participation arrangements as has been developed in the critical PUS tradition by people like Les Levidow, Brian Wynne, and Alan Irwin, and it certainly merits testing. However, there 
is no way of knowing in advance whether, to what extent and in what sense we are dealing with deliberate manipulation in certain cases. Thus, the perspective suggested by Dominique Pestre can alert us to the possibility of manipulative undercurrents in actual participative practices and arrangements, yet it cannot replace empirical analysis. We would thus caution against moving too quickly from advocating participation to debunking it, for both positions maintain a theoretical, normative perspective. We rather recommend examining what is going on and what participation actually does.

Critical research in the PUS tradition has already provided a series of analyses of statesponsored participatory exercises, mostly in reference to the controversy over genetically modified organisms and their use in agriculture (Irwin, 2006; Irwin and Michael, 2003; Levidow and Marris, 2001; Wynne, 2006). Participatory exercises, researchers have shown, were heavily compromised by a problem-definition that narrowed the issues at stake down to issues of risk and safety, suggesting a policy approach characterised by regulation and oversight, performed by technical experts. This framing, on the other hand, marginalises broader, socio-economic and political concerns about, for instance, industrial agriculture, power relations in the agroindustry, or an illusory obsession with technological fixes. Les Levidow (1998) coined the term "biotechnologizing democracy" as opposed to "democratizing biotechnology," in order to describe approaches that define both the problem and the proposed solution in terms of technology rather than in terms of socio-political and socio-economic relations. While conceding that public participation can provide opportunities to take public concerns into account and render science governance more accountable, critics have pointed out a series of limitations and restrictions that seriously impede the democratic potential of the respective participatory exercises. In brief, the diagnosis is: too little, too late. The limitations, deficits and constraints of participatory exercises, specifically as they are built into the respective format of the exercise, may concern the range of participants, the scope of the agenda, the formulation of policy problems, or the stage of the policy process at which participation comes into play. Formats are extremely important since designing the format gives organisers a considerable amount of control over how the issue is framed which in turn influences the scope and direction of the ensuing results (Stirling, 2008). In this article, we suggest that alongside exposing what public participation exercises do not do, what they fail to do, what their deficits and restrictions are, it is important to investigate what they are doing. We specifically highlight the dimensions of knowledge generation, education and subject construction built into actual participatory arrangements. This view presupposes to some extent an empirical rather than a normative approach. Empirical studies on public participation in science so far have mainly focused on questions of which impact and effects certain participatory exercises had (Bütschi and Nentwich, 2002; Chilvers, 2008; Hennen, 2002; Schicktanz and Naumann, 2003). Taking a broader view, Gabriele Abels and Alfons Bora have developed a taxonomy of formats of participatory arrangements supplemented with empirical examples. Their taxonomy is primarily based on the respective ideas of democracy and legitimacy underlying the individual formats but also addresses the respective ability of certain formats to solve policy problems (Abels and Bora, 2004).

In the following, we also present a typology of formats, but unlike that presented by Abels and Bora it does not refer to criteria of efficiency or legitimacy, but to the way the subject, namely the respective public invited to participate, is constructed through these formats. We hold that the construction of publics is one of the most fundamental aspects of participatory events and arrangements and requires further empirical research. "The public," we argue, is never immediately given but inevitably the outcome of processes of naming and framing, staging, selection and priority setting, attribution, interpellation, categorisation and classification. In this respect, our approach contributes to other recent constructivist work 
concerned with the question of how the subject( $s$ ) of participation, such as citizens, publics, social groups, take shape in certain formats and contexts and on the basis of certain explicit or implicit assumptions and ideas (Felt and Fochler, 2008; Irwin, 2001, 2006; Lezaun and Soneryd, 2007; Michael, 2009; Nowotny et al., 2004; Reardon, 2007; Reynolds et al., 2007). Here, we look at one sub-sector of participation, namely formal, discrete, state-sponsored exercises of participation in the issue area of genetic testing in Germany and the UK. We do not assume that this typology is universally applicable throughout different polities or issue. Still, it may serve to inspire further research on other issue areas or serve as a comparison.

\section{Doing publics}

Issues of biotechnology and biomedicine, such as genetically modified crops, embryonic stem cell research, or genetic testing have long featured prominently in the new arenas of public engagement. Interestingly, in the case of genetic testing, the increasing activity of public participation does not correlate to an increase in public controversy on the issue. Many genetic testing practices, especially in the area of prenatal genetic diagnosis, have become routine in health care, and although there is still some unease in parts of the public, unlike with technologies such as nuclear energy, genetically modified food, or embryonic stem cell research, there is not really a fundamental controversy any more over the question of whether methods for testing certain genetic conditions should be developed or not. What remains contested, albeit to a different degree in Germany and the UK, are certain applications of such methods, such as pre-implantation genetic diagnosis (PGD). Except for some lingering concerns about $\mathrm{PGD},{ }^{12}$ the glaring utopian and dystopian visions of the 1980s have largely given way to more post-euphoric and post-apocalyptic discourses, rather emphasising the limited power of genes and genetics and distinguishing between different purposes and areas of application (Schultz et al., 2007). Specifically in the UK, the intensity of public unrest in this issue area has decreased over the past two decades, while discourses on public participation in science have increased. This is not to suggest that there is a direct correlation in the sense that the less controversial an issue becomes the more institutional participation we can expect. Yet, this observation refutes to some extent, or at least qualifies, the suggestion that an increased emphasis on public participation is to be understood as a response to public opposition to biotechnology (Goven, 2006). While this may be a plausible interpretation for a certain phase in the history of participatory arrangements, we have to consider the possibility that this phase is superseded by one in which the institutionalisation of participation has assumed a dynamics of its own (Bauer et al., 2007).

Public participation, we should stress, is not co-extensive with formal arrangements in which people are invited by organisers to participate in certain ways and certain roles. Political participation can take many forms, many of them informal and uninvited, such as media campaigns, sit-ins, go-ins, public debates or the like, initiated by self-selected actors who turn into participants through collective actions. A high profile case of informal and civil society-led participation in our issue area was the 1000Fragen.de campaign in Germany started in 2002 by the Aktion Mensch, an NGO of and for people with disabilities and their families (Waldschmidt et al., 2009). However, for reasons that deserve further investigation, in the realm of scientific governance, the term "public participation" has become largely synonymous with discrete, formal, government-sponsored arrangements. These are typically events that follow certain rules that have been set in advance. They are temporally discrete in that, in contrast to informal, often civil society-led participatory activities, which are typically temporally diffuse, they have a clearly defined beginning and end. Mostly, the sites where participation is supposed to take place, whether virtual or real, are well defined, again in contrast to more informal, 
diffuse forms of public participation. In the following, we will focus on formal, discrete, state-sponsored types of arrangements in the issue area of genetic testing in Germany and the UK and survey this landscape from the perspective of how publics are constructed. We suggest that this landscape is populated by four major constructions of publics:

- the general public,

- the pure public,

- the affected public,

- the partisan public.

Each of these figures is brought into being through certain technologies of interpellation, allocates certain speaking positions while precluding others, and embodies certain assumptions, priorities and purposes. We can also see that organisers appreciate some of these publics and subject positions more strongly than others, endowing special significance mainly to the pure and the affected public while tending to depreciate the partisan public. The typology is inspired by Larry Reynolds and Bronislaw Szerszynski's distinction between the engaged and the pure or purified public in the GM Nation debate in the UK (Reynolds et al., 2007). However, as regards human genetics, we suggest a further distinction between the pure public and the general public and the introduction of a figure specifically appearing in this area, namely the affected public. Who are these constructed publics and where do we encounter them?

\section{The general public}

The general public is constructed mainly through opinion polls which form a regular element in many consultation processes referring to issues of human genetics and other technoscientific issues in the UK. Examples include opinion polls during the consultation process held conjointly by the Human Fertilisation and Embryology Authority (HFEA) and the Human Genetics Commission (HGC) on pre-implantation genetic diagnosis (PGD) (HFEA and HGC, 2001) or a quantitative study on public attitudes as one element of the consultation process Whose Hands on Your Genes? (HGC, 2000), which dealt with the use of personal genetic information in general by the HGC. The purpose of such polls is to provide government and its advisory system with a survey of the public's understanding of, views on and attitudes towards human genetics and the ways to deal with it (HGC, 2001).

Polls and surveys can be understood as "technologies of elicitation" (Lezaun and Soneryd, 2007). They should not be mistaken for referenda, as the current chair of the HFEA, Shirley Harrison, made this quite clear when she launched the consultation on hybrids and chimeras in 2007:

It is important to remember that this is not a referendum with "votes" counted for or against particular types of research. Instead, we want to understand why people feel worried or enthusiastic about this research in order to help us make a judgement about the best way to proceed. (HFEA, 2007)

The purpose of these polls was first of all to supply the government and the advisory system with data about people's attitudes, views, thoughts and feelings concerning human genetics, and not, at least not directly, to guide the government's course of action. In other words, its main purpose is knowledge production, not political decision-making. Therefore, the statistical distribution of opinions within the population is not of so much interest for the organising bodies. One of our interviewees, an HFEA manager, explained that the instrument of opinion polls was not interesting to the HFEA as a "quantitative method in a strict statistical 
sense but as a method to compare the scope of arguments resulting from a poll with the scope of responses to the consultation paper" (Int. 17). Consequently, the advisory body does not necessarily feel committed to adopt the outcomes of these polls and incorporate them into their recommendations, as another interviewee, a former member of the HGC, told us:

So you have to be quite careful with polling and sort of justify why you come to a different conclusion. But I sort of rationalised it in my mind, that it is not unlike the way in which a court or a judge weighs evidence, you know some evidence is more persuasive because it is nearer, or because it is more relevant, or because it is more recent, or because you like the witness better, you trust the witness better. (Int. 20)

The public here is not so much the sovereign, giving political input, as the witness, providing evidence. The evidence, however, is raw and potentially unreliable and therefore needs to be weighed and interpreted, which in turn is the task of the expert advisor, performing the role of the judge who supposedly has a more neutral, encompassing and unbiased perspective on the subject. In short, making use of the general public's views involves a considerable amount of constructive, interpretative activity on the part of the experts.

\section{The pure public}

Quite a different figure, based on a different idea and, at least ideally, fulfilling a different purpose is the pure public. In the issue area of genetic testing, we encountered it in the form of citizen juries, citizen conferences and particularly youth conferences, the latter being events with only young people invited as participants. In contrast to opinion polls and surveys, these formats are characterised by comparatively small groups, personal interaction, and a limited duration. Participants are conceptualised as citizens or laypeople, meaning that they are interpellated as individuals, not as members of an organisation or an interest group. In addition, their main qualification is exactly their ignorance concerning the issue at stake and, at the same time, their amenability to education. The purpose of interpellating the pure public is not to estimate the distribution of certain attitudes, preferences and opinions within the population but to transform, shape and refine these. Whereas the main idea of opinion polls is to produce knowledge about the attitudes, ideas and viewpoints "out there," the main idea of setting up a citizens' jury, as a member of the HGC told us, is education:

If you want to know what sort of $50 \%$ of the population think about something, then you do a poll .... But they don't want to measure, they want a measure of how people would feel, when they are ignorant of the issue and when they are completely educated. (Int. 4)

As the quote shows, knowledge production in a sense is a goal here too, but the outcome is rather knowledge about how to convert naïve citizens into mature citizens.

This idea informed the Consensus Conference on Genetic Diagnosis that took place in Dresden in 2001, which was the first citizen conference in Germany, initiated by the Ministry of Education and Research and organised by the Hygiene Museum Dresden (Deutsches Hygienemuseum Dresden, 2002). The organisers invited 19 citizens, carefully selected from a pool of persons whose names and addresses the organisers had obtained through a random process. The composition of the group was meant to mirror the composition of the population at large, including employed and unemployed, older and younger people, men and women, students and pensioners. At the same time, participants must not be engaged in an interest group or an NGO or be a member of, for instance, a biotech company or a professional in the biosciences. Such closeness to the issue at stake was assumed to cause bias and partisanship; only unspoiled minds would qualify. 
The citizens group would choose a topic for their deliberations (they picked PGD, prenatal testing and preventive testing), select experts from a pool recruited by the organisers, crossexamine them, discuss a series of statements solicited in advance from authorities in relevant fields and deliberate among themselves over several days and finally issue a verdict on the three subjects (Fraunhofer-Institut für System- und Innovationsforschung, 2002; Schicktanz and Naumann, 2003).

The main purpose of the experiment was not to influence policy-making in the area of genetic testing. In fact, commentators agree that it had relatively little impact on formal policy. Rather, the idea was to perform an ideal type deliberation process among as yet genetically illiterate participants in order to answer the questions whether, and how, these blank minds could be transformed into knowledgeable and mature citizens, capable of making reasonable judgements on complicated issues of science policy. The consensus conference was thus meant as a reference model for organising discourse events and exercises in public involvement. Implicitly, the main addressees of this performance were not only journalists and policymakers, but also the growing community of discourse professionals - social scientists studying new experiments with public participation in science. Social scientists attending the final, public event of the conference, report that the audience was to some extent composed of discourse professionals (Sperling, 2007).

Hence, the primary purpose of this format is to demonstrate the capacity of ordinary citizens to refine their views and attitudes through the process. The same applies, as an interviewee from the HGC put it, to the use of citizen juries in the context of HGC consultations:

... they specifically wanted to take people who probably know nothing or very little about forensic use of genetic information here, apart from what they see on television, and to spend two or three days with them and have real expert witnesses and educate them about the issues involved, and then ask them, after these few days, how they feel about it. Just to get a flavour. (Int. 4)

However, the format implies a paradoxical imperative: on the one hand the deliberation process is supposed to be authentic, not distorted or manipulated, on the other hand it is supposed to induce a change of attitudes and a process of self-transformation on the part of participants. This dilemma forms a constant motor for the permanent quest to improve and refine the methods and procedures of this format. The idea is to give non-directive balanced information on the issue in order to enable participants to make mature and informed personal judgements. However, the goal that participants will actually change opinions in a substantive way implies a certain temptation for the organisers of such events to select the informative or educative inputs given to participants by experts or via dossiers in order to achieve this goal of self-transformation. If polls and surveys serve as technologies of elicitation, these small formats, based on personal interaction within a certain period of time work as technologies of transformation, meant to achieve and to demonstrate the educational effect of carefully conducted citizen deliberation.

This idea comes to the fore even more clearly in the format of so-called youth conferences, which have been performed both in the UK and in Germany. In the UK, a Youth Citizen Jury was set up and formed part of the HGC's consultation on Choosing the Future: Genetics and Reproductive Decision-making in 2004. A group of people aged 16 to 19 had been invited to attend a meeting with experts and members of the HGC to discuss topics of genetics and reproductive medicine - after, however, having been exposed to pertinent educational materials (Int. 22; HGC, 2006: 8f.).

A similar discursive event, the Leipzig Youth Conference, took place in Germany in May 2006, initiated and financed by the German Federal Ministry for Education and Research 
(BMBF). The conference included a first phase, in which participants received a scientific education about human genetics meant to provide them with the prerequisites for further deliberation. In a second phase, the young people were asked to create films, posters or other media products presenting their views on the issue, and to set up a catalogue with their demands concerning the regulation of genetic testing. These products were to be presented to the public at the final event of the process. Policy-makers from the Bundestag or the cabinet, although they had been invited, were not present. At this event, the young participants were generally constructed not only as uninformed and as people with a need to learn how to reflect and how to participate, but also as a homogeneous social group, an amorphous mass of nameless specimens (unlike the experts, the young people were not introduced by name!) who supposedly do not hold controversial views within the group on the issue. Although the different groups who had prepared different media products for the event presented very different political positions on genetic testing, the purpose of the event was not to perform a discussion among the group but to integrate "the" view of "the" young people into one final document in order to represent "the" authentic view of adolescents. ${ }^{13}$ Thus, the format ruled out the possibility that "the youth" could present conflicting demands, producing instead one single catalogue of demands of "the young generation."

The pure public thus turns out to be a purified public: carefully selected to exclude people who hold strong opinions, or who are engaged or politically organised. Or, if they do hold such views, they are prevented from presenting them. As such, the pure public has little chance of acting on an equal footing with science and government. Rather it resembles a kind of collective human subject in a series of science-society discourse experiments.

\section{The affected public}

In 2001, the UK Human Genetics Commission set up a consultative panel, made up of some 100 people "with direct experience of living with genetic disorders" (HGC, 2008). Panel members interact with the HGC mainly by correspondence, giving recommendations or opinions on reports or draft reports which the HGC sends to them. In addition, since 2005 the HGC decided to have an annual meeting with the members of the consultative panel. The panel is composed of people with single gene disorders, chromosomal or multi-factoral disorders, childhood and adult onset disorders. The members may be affected themselves or are carriers or are caring for a child or another family member who is affected.

Members are considered first hand experts of being affected, directly or indirectly, by a genetic or chromosomal disorder; capable of providing a sort of expertise that no other type of experts could provide. This type of expertise stems from intimate experience with the disorder, from either bodily experience or personal life. The idea behind involving this type of public is not, as in the case of a citizens' jury or a youth conference, to gather some naïve and yet unspoiled minds and give them a proper education but rather the educational process works the other way round. The affected experts provide not only knowledge about living with a genetic disorder, but also emotional education, in particular in face to face interactions between the members of the HGC and the members of the consultative panel, enabling the traditional experts to reconsider their opinions and to enlarge their views. The HGC members explain that being able to personally talk with the consultative panel members in small table groups during a meeting was a most helpful experience in preparing the Making Babies report (HGC, 2006). Another commission member recalls:

Another consultation we had I think that was very valuable. There is a group of people with genetic disabilities who are consulted on a regular basis.... They spent a whole day sitting 
in meetings in open discussions in a big room, you know, in a table like this and they did have a chance to really go deeply into things ... Somehow the fact that you met face to face with people who were involved was helpful. I am sure that where people did have strong points, these would have been repeated and remembered by the commission. (Int. 1)

It is almost as if the personal interaction with people personally affected by a genetic disorder could have a cathartic effect on the traditional experts.

Yet, although it is personal, first hand experience which makes these participant-experts so valuable, the affected public is far from being a given. On the contrary, it is the result of sophisticated efforts of engineering, as one of our interviewees explained:

... basically they sent this kind of thing around, saying, would you be eligible to join? Would you like to join? Telling people what is involved. ... They put it into GP surgeries and they sent them to GIG [Genetic Interest Group, KB], whoever they could think of. And then, they got a lot of applicants, and then there was a certain amount of engineering involved, because they wanted a range of experiences as wide as possible, so people were asked what their genetic condition was, were they affected directly or were they looking after someone, or were they someone who had a condition run in the family and they didn't know if they were affected yet, so that kind of thing. It was to get as broad a picture as possible, and then so there was a little bit of engineering I think, because they would get a lot of people with a certain genetic condition ... and they wanted to balance. (Int. 4)

Another aspect of engineering the affected public consisted in excluding people organised in disability organisations. The high regard in which experts hold the members of the affected public stems not least from a discursive operation that opposes being affected to being a lobbyist. Again, our interviewee from the HGC explains:

... we were very clear when we take new people on, as we did do quite recently a few months ago: If someone is a member of an organisation, to say, a disability organisation, we are very clear, that the role of the panel is not a forum for lobbying, you know, and ... I mean, it is no doubt, I can imagine, that it is an attractive position, if you are a lobbyist, to have the direct ear of the commission, because obviously they are advising government. But the panel is just not there for. It hasn't happened in my time that there is someone very strongly trying to lobby, but I think if it did happen it would be our responsibility to sort of say to them, look that's is not what you are there for. (Int. 4)

Yet, members of the Genetic Interest Group were not disqualified, even though it is a quite influential umbrella organisation of patient groups clearly lobbying in favour of genetic research. The GIG was explicitly asked to name potential panellists - whereas members of a disability rights organisation, in the quote above, count as lobbyists. In this case, authority seems to derive from a medicalised or even molecularised version of affectedness. The position of a disability rights activist who sees her life as being affected by social views and practices rather than by a genetic condition is not an available speaking position here.

This was different in the case of the Dresden citizen conference on genetic diagnosis, although we can also see authentic experts here. The pool of experts offered to the citizen group comprised a number of people living with a disability. Disability, however, was constructed as a social relation that requires social policy actions rather than a medical condition that required medical research. Authenticity thus also emanates from personal bodily experience, but this experience is not necessarily defined in medical or genetic terms. ${ }^{14}$ 


\section{The partisan public}

The authentic public is implicitly contrasted to another, not so cherished type of public, which we term the partisan public. It consists of organisations - not of individuals - who hold strong collective opinions on the issue or have a particular interest. Interviewees usually referred to such groups as stakeholders or lobbyists - and they tended to speak rather pejoratively about them. If the pure public is constituted by naïve, non-organised, non-politicised individuals, stakeholders form an "impure public" of opinionated trouble-makers. In particular the speaking position of being a representative of an activist organisation, an NGO, or an interest group, typically responding to consultation documents sent out by the UK advisory bodies, was discredited for instance as a "minority of highly vociferous groups" (Int. 20), a "small set of people" (Int. 6), or a "self-selecting sample" (Int. 17) that lacks democratic legitimacy. A former member of the HGC, for instance, told us:

There is always a problem in lobbying, you are always going to hear from a minority of highly vociferous groups whereas you don't hear from that sort of 95 per cent of people who don't feel strongly about things. (Int. 20)

Nevertheless, soliciting stakeholders for comments on a certain issue forms a well established element in the consultation processes in the UK. Usually, such a consultation process includes a phase in which the consultation document is sent out to different sorts of groups and organisations with the aim of eliciting feedback. The purpose of this practice is not, as interviewees emphasised, to find out about the distribution of views in the population but rather searching the political landscape for viewpoints and arguments as a prerequisite for developing an overview of sophisticated arguments to be presented to the government. In this vein, a member of the HGC thought stakeholder opinions to be valuable, even if not representative:

So, there are so many different ways of trying to get - and obviously the way of sending out the consultation document, you only get responses from a very small set of people, but nonetheless they are often very well reasoned and thought through responses. (Int. 6)

Being representative, however, is not the main purpose of collecting partisan views: "The commission [HGC] is much more concerned to work, ensuring that it fleshes out the viewpoints that exist around an issue. That is why in a sense there are multiple ways in which you can input to the commission" (Int. 13). Or, as an interviewee from the HFEA explained:

We weren't doing that in order to get a quantitative sample, we were doing it to draw out the arguments ... So the reason for doing that is to draw out the arguments in order that they can be laid out to the authority and then be appraised. (Int. 17)

Hence, the role of stakeholders and organised groups here is not so much being a party in an ongoing negotiation process but rather being a resource for gathering arguments assumed to exist "out there" and to be more sophisticated and complex than the arguments gathered through polls. This collection of arguments, again, forms the raw material for the advisory system's generation of a more refined and sophisticated overview of arguments that it will present to the government. One interviewee, a member of an NGO, felt rather exasperated about this process, explaining that participation in stakeholder consultations consumes a lot of energy while being of questionable political value to them as a political group:

Yea, well I think, you actually have to participate. ... And we do spend an awful lot of time answering consultations, I mean, we also had the government had a number of them, 
Table 1. Types of publics constructed through formal participatory arrangements in the area under study

\begin{tabular}{|c|c|c|c|}
\hline & practices and settings & speaking position available & $\begin{array}{l}\text { designated outcome and type } \\
\text { of technologies }\end{array}$ \\
\hline $\begin{array}{l}\text { the general } \\
\text { public }\end{array}$ & opinion polls, surveys & anonymous individuals & $\begin{array}{l}\text { knowledge about people's attitudes and } \\
\text { views; scope of arguments; material for } \\
\text { developing more sophisticated arguments; } \\
\text { technologies of eliciting views and opinions }\end{array}$ \\
\hline $\begin{array}{l}\text { the pure } \\
\text { public }\end{array}$ & $\begin{array}{l}\text { citizen conferences, } \\
\text { citizen juries, } \\
\text { consensus conferences, } \\
\text { youth conference }\end{array}$ & $\begin{array}{l}\text { concrete individuals; } \\
\text { naïve citizen as } \\
\text { subject of education }\end{array}$ & $\begin{array}{l}\text { educating citizens; demonstrate the capacity } \\
\text { to transform the naïve citizen into the } \\
\text { mature citizen; knowledge about the } \\
\text { transformation process; technologies of } \\
\text { self-transformation }\end{array}$ \\
\hline $\begin{array}{l}\text { the affected } \\
\text { public }\end{array}$ & $\begin{array}{l}\text { the consultative } \\
\text { panel }\end{array}$ & $\begin{array}{l}\text { concrete individuals; } \\
\text { the authentic expert }\end{array}$ & $\begin{array}{l}\text { educating the expert; first hand knowledge } \\
\text { about life with a genetic disorder }\end{array}$ \\
\hline $\begin{array}{l}\text { the partisan } \\
\text { public }\end{array}$ & $\begin{array}{l}\text { stakeholder } \\
\text { consultations }\end{array}$ & $\begin{array}{l}\text { interest groups, } \\
\text { political organisations }\end{array}$ & $\begin{array}{l}\text { knowledge about the landscape of possible } \\
\text { arguments; technologies of eliciting } \\
\text { viewpoints and arguments }\end{array}$ \\
\hline
\end{tabular}

and then the STC, and the DoH, and feel sometimes that all you do is to genuinely have to produce responses to consultations [laughs] and then the question is: So what? They are easily dismissed afterwards by saying well, only those who are interested in these issues take part so it doesn't really represent public opinion. (Int. 22)

Thus, what the interviewee is saying is that the government, after having actively constructed all these publics still has the option to privilege one form of public and its outcomes at the expense of others, particularly to privilege the outcomes of pure publics at the expense of partisan publics.

The chart in Table 1 gives an overview over the different types of constructions of publics we found in our case study.

\section{Conclusion}

This paper has argued that at a time when public participation in science has become a central concern of governments and participation exercises proliferate, it is no longer sufficient to discuss the desirability of participation on a theoretical, normative level; we need a critical inventory of the formats, methods and mechanisms of participation derived from empirical research. It is also not sufficient, we have argued, to assess actual participatory arrangements in terms of their limits and shortfalls in relation to some underlying normative idea; we need rather to understand how subjects of participation, such as publics, citizens, and stakeholders are actively constructed through these arrangements and how certain speaking positions are made available while others are not. It is true that no form of participation, whether informal or formal, government-sponsored or initiated by civil society, offers an unlimited variety of speaking positions from which participants can freely choose at any time, since there will always be formal or informal rules, expectations and conventions. Still, it is particularly important to scrutinise government-sponsored participatory exercises since in this case control over subject constructions and speaking positions lies far less with participants themselves than in the hands of sponsors and organisers.

We conclude our case study with three observations: first, the proliferation and dynamics of public participation exercises, in our case study, cannot be attributed to an increase in 
public concern but have become independent to some degree of the dynamics of public concern and societal controversy. Government-sponsored public participation exercises have outlived the societal and cultural conflicts that characterised the debate on genetic technology in the 1980s and 1990s. This, however, also means that control over the construction of subjects of participation and the availability of speaking positions has shifted towards governments and organisers.

Second, it seems that the main purposes of the participatory processes we looked at are knowledge production and education, rather than political deliberation and decision-making. Participants are mainly conceived as subjects of proper education (as in consensus and particularly youth conferences) or as providers of views and attitudes (the general public), of arguments (the partisan public), or authentic experiences (the affected public), the knowledge of which is considered useful for the government or the advisory system when they develop their course of action.

Third, participatory exercises display a certain tendency to construct the subjects of participation in a way that allows for harmonious, supposedly win-win constellations that theoretically can benefit everyone, at the expense of more conflictual or antagonistic ones. While the stakeholder public does have its place among the diversity of publics and is valued as a source of information about the variety of possible arguments concerning the issue at stake, its reputation certainly ranks below that of the general, the affected, and the pure public. Publics based on the idea of consensus and education are held in higher regard and ascribed a higher moral authority than those based on the idea of conflict and struggle. While the concept of "deliberative manipulation" would be misplaced here, since it implies the assumption of a coherent, strategically acting subject, it is still the case that constructions such as the pure public, the affected public, and even the general public make it difficult to take an adversarial stance towards certain issues or actors or to interpret the issue as a matter of power relations.

Further research is needed to reinsert the dimension of conflict and struggle into the study of public participation, which would also include addressing questions of power and interest. On a micro level, this research could illuminate the conflictual interactions between participants, organisers, sponsors and other actors within and about certain participatory exercises, guided by the questions of whether and how the construction and ascription of speaking positions itself at times becomes a subject of contestation and struggle among actors, including participants. On a macro level, it would be useful to get a broader view of the development of both informal, civil society-led and formal, government-sponsored participation across various issue areas, in relation to each other and over time in order to explore whether there is a tendency to privilege certain ideas and constructions of publics over others and to identify the conflicts, interests and struggles behind this development.

Here we can link our analysis back to the construction of policy problems as highlighted in critical PUS studies. If there is a tendency in recent participatory procedures to privilege certain speaking positions while discrediting others, how does this tendency affect the construction of policy problems and thereby indirectly the construction of possible solutions? For more robust conclusions, further detailed empirical research is needed, research that would study the co-production of subjects, knowledge, policy problems and policies in and through participation practices (see also Schultz et al., 2007). However, the picture emerging from our case study is that the most cherished constructions of publics - the pure public and the affected public - provide only individualised speaking positions. Relationships are represented only insofar as they originate in the private sphere, such as family relations in the case of the affected public, but not as they originate in power relations, relations of conflicting interests or political conflict. Participants' contributions on the issue at stake, within this framework, can take the form of personal convictions, values, views, experiences, or emotions and the 
issue at stake tends to be fragmented into a multiplicity of personal, equally authentic views, which, as such, can be respected but hardly criticised. Issues of distributive justice, research priorities, economic interests, and effects of biotechnologies on society as a whole, which would require speaking positions of social or political groups, are hard to articulate within such a framework. The tendency towards individualised, "naïve" or "authentic" subject constructions implies a tendency to fragment, ethicise, and depoliticise the issue at stake and to foreclose more antagonistic political contestation. However, these constructions may always be challenged by participants within state-sponsored participatory arrangements or by those participating in informal civil society-led debates.

\section{Acknowledgements}

Research for this article was conducted in the context of the research project PAGANINI (Participatory Governance and Institutional Innovation), funded under the Sixth EU Framework Programme, Contract number CIT2-CT-2004-505791 (http://www.paganini-project.net/). The authors wish to thank Alfred Moore, Kevin Burchell, Ana Delgado, Martin Bauer and of course the Paganini team for valuable comments on former versions of this paper.

\section{Notes}

1 For recent discussions see Burchell et al., 2009: Chilvers, 2008; Einsiedel and Kamara, 2006; Felt and Fochler, 2008; Gottweis et al., 2008; Irwin, 2006; Lengwiler, 2008; Levidow, 2007; Stirling, 2008.

2 Note, however, that Jasanoff qualifies her call, arguing that formal mechanisms of participation alone will not suffice but that we need new institutional settings which encourage both citizens and experts to address uncertainties and the unknown.

3 See Braun et al., 2008; Frewer and Salter, 2007; Rowe and Frewer, 2004; Salter and Jones, 2002.

4 The issue areas under study were highly diverse, encompassing embryonic stem cell research, genetically modified organisms, food scares such as BSE, the protection of endangered species, and genetic testing, each case study referring to two or more European countries and/or levels of governance. The project as such, its general background and the difficulties and benefits of its specific approach will be discussed elsewhere (Gottweis et al., forthcoming).

5 The research draws inter alia from the concept of issue publics as developed by Dewey (1991). For a recent discussion of the co-evolution of issues and publics see also Marres (2007).

6 This methodological practice of comparing cases as diverse as these is discussed by Anne Loeber and Yrjö Haila (2009).

7 These shifts will be discussed in more detail elsewhere (Braun and Schultz, forthcoming).

8 In the UK, between 1999 and 2009 the HFEA and the HGC together undertook at least six public consultations directly relating to matters of genetic testing, such as PGD, reproductive decision-making, sex selection, or genetic privacy. A public consultation typically comprises the use of different formats, such as polls, focus groups, or citizen juries. In Germany, a citizen conference was organised by the Dresden Hygiene Museum in 2000-01 and a youth conference by the University of Leipzig in 2005-06, both using government funding. Another participatory event dealing, inter alia, with issues of genetic testing in Germany was the media campaign 1000Fragen (Waldschmidt et al., 2009). This, however, was not really a formal, government-sponsored event since it was organised by an NGO and also much less formalised in terms of participants, time and space.

9 While participatory and deliberative democracy seek to extend the meaning of democracy beyond the mechanisms of representation, they are not synonymous concepts. Following Dryzek (2002), the emphasis of participatory democracy is on who can participate, seeking to extend the scope of participants, while a deliberative democracy approach highlights how participation takes place and seeks to establish more authentic, undistorted forms of interaction, raising the quality of the debate rather than just the number of participants.

10 For a recent discussion of deliberative democracy and scientific governance in the case of bioethics politics see Moore (forthcoming).

11 The concept of "the political" is taken from Carl Schmitt and is not unproblematic. It does not refer to political action in the sense of contesting interests or opinions nor to struggles about the meaning of the common good but to the struggle between "friend and foe" conceived as homogenised collectivities. 
12 In Germany, PGD is still prohibited. The question of whether it should be legalised or not was the subject of a huge controversy in the years 2000-01 which ended with maintaining the legal ban. In contrast, prenatal genetic diagnosis is broadly applied and hardly contested in Germany as in the UK. In the UK, PGD is principally legal but certain applications such as using it for the purpose of sex selection are subject to controversy.

13 Participant observation by Susanne Schultz.

14 The small number of affected publics constructed by and acting in formal participatory arrangements does not allow for generalisations about country-specific variations of this type. For such a comparison, one would have to scrutinise participatory arrangements throughout different issue areas in the respective countries, which would be worth doing though.

\section{References}

Abels, G. (2007) "Citizen Involvement in Public Policy-making: Does it Improve Democratic Legitimacy and Accountability? The Case of pTA," Interdisciplinary Information Science 13(1): 103-16.

Abels, G. and Bora, A. (2004) Demokratische Technikbewertung. Bielefeld: transcript.

Bauer, M. W., Allum, N. and Miller, S. (2007) "What Can We Learn from 25 Years of PUS Survey Research? Liberating and Expanding the Agenda," Public Understanding of Science 16(1): 79-95.

Braun, K. (2005) "Not just for Experts: The Public Debate on Reprogenetics in Germany," Hastings Center Report 35(3): 42-9.

Braun, K. and Schultz, S. (forthcoming) "Governing Genetic Choices: Participatory Exercises, the Construction of Publics and the Quest for Authenticity," in H. Gottweis, M. Hajer and A. Loeber (eds) Life Matters: New Practices of Participatory Governance in Europe.

Braun, K., Moore, A., Herrmann, S. and Koenninger, S. (2008) "Die Sprache der Ethik und die Politik des richtigen Sprechens. Regulative Ethikregime in Deutschland, Frankreich und Großbritannien," in R. Mayntz, F. Neidhardt, P. Weingart and U. Wengenroth (eds) Wissensproduktion und Wissenstransfer. Wissen im Spannungsfeld von Wissenschaft, Politik und Öffentlichkeit, pp. 221-42. Bielefeld: transcript.

Burchell, K., Franklin, S. and Holden, K. (2009) Public Culture as Professional Science: Final Report of the ScoPE Project (Scientists on Public Engagement: From Communication to Deliberation?). London: BIOS. URL (consulted August 2009): http://www.lse.ac.uk/collections/BIOS/scope/scope.htm

Bütschi, D. and Nentwich, M. (2002) "The Role of Participatory Technology Assessment in the Policy-making Process," in S. Joss and S. Bellucci (eds) Participatory Technology Assessment: European Perspectives, pp. 235-56. London: University of Westminster Press.

Chilvers, J. (2008) “Deliberating Competence," Science, Technology, and Human Values 33(2): 155-85.

Collins, H. M. and Evans, R. (2002) "The Third Wave of Science Studies: Studies of Expertise and Experience," Social Studies of Science 32(2): 235-96.

Deutsches Hygienemuseum Dresden (2002) Bürgerkonferenz Streitfall Gendiagnostik 23.-26. 11. 2001. Dresden: Deutsches Hygienemuseum Dresden.

Dewey, J. (1991) The Public and its Problems: An Essay in Political Inquiry. Athens, OH: Swallow Press/Ohio University Press.

Dryzek, J. (2002) Deliberative Democracy and Beyond: Liberals, Critics, Contestations. Oxford: Oxford University Press.

Einsiedel, E. and Kamara, M. W. (2006) "The Coming of Age of Public Participation," in G. Gaskell and M. W. Bauer (eds) Genomics and Society: Legal, Ethical and Social Dimensions, pp. 95-112. London: Earthscan.

Felt, U. and Fochler, M. (2008) "The Bottom-up Meanings of the Concept of Public Participation in Science and Technology," Science and Public Policy 35(7): 489-99.

Felt, U. and Wynne, B. (2007) Taking European Knowledge Society Seriously. Brussels: European Commission. URL (consulted February 2009): http://ec.europa.eu/research/science-society/document_library/pdf_06/ european-knowledge-society_en.pdf

Fischer, F. (2000) Citizens, Experts, and the Environment. Durham, NC and London: Duke University Press.

Fischer, F. (2005) "Are Scientists Irrational? Risk Assessment in Practical Reason," in M. Leach, I. Scoones and B. Wynne (eds) Science and Citizens: Globalization and the Challenge of Engagement, pp. 54-65. London: Zed Books.

Fraunhofer-Institut für System- und Innovationsforschung (2002) Begleitende Evaluation der Bürgerkonferenz Streitfall Gendiagnostik. Karlsruhe: Fraunhofer-Institut für Systemtechnik und Innovationsforschung (ISI).

Frewer, L. J. and Salter, B. (2007) "Societal Trust in Risk Analysis: Implications for the Interface of Risk Assessment and Risk Management," in M. Siegrist, T. C. Earle and H. Gutscher (eds) Risk Management and Public Trust, pp. 143-58. London: Earthscan. 
Gottweis, H. and Braun, K. (2007) Participatory Governance and Institutional Innovation [PAGANINI], Contract No. CIT2-CT-2004-505791. Deliverable No. 18. Final report. URL (consulted August 2009): http://www.univie. ac.at/life-science-governance/paganini/output.htm

Gottweis, H., Braun, K., Haila, Y., Hajer, M., Loeber, A., Metzler, I., Reynolds, L., Schultz, S. and Szerszynski, B. (2008) "Participation and the New Governance of Life," BioSocieties 3(3): 265-86.

Gottweis, H., Hajer, M. and Loeber, A. (eds) (forthcoming) Life Matters: New Practices of Participatory Governance in Europe.

Goven, J. (2006) "Dialogue, Governance and Biotechnology: Acknowledging the Context of the Conversation," Integrated Assessment Journal 6(3): 99-116.

Hennen, L. (2002) "Impacts of Participatory Technology Assessment on its Societal Environment," in S. Joss and S. Bellucci (eds) Participatory Technology Assessment: European Perspectives, pp. 257-75. London: University of Westminster Press.

Herrmann, S. L. (2009) Policy Debates on Reprogenetics: The Problematization of New Research in Great Britain and Germany. Frankfurt a.M. and New York: Campus.

HFEA (2007) "Should We Allow the Creation of Human/Animal Embryos?," Press release, 26 April, URL (consulted October 2008): http://www.hfea.gov.uk/en/1518.html

HFEA and HGC (2001) Outcome of the Public Consultation on Preimplantation Diagnosis. URL (consulted February 2008): http://www.hfea.gov.uk/docs/PGD_outcome.pdf

HGC (2000) Whose Hands on Your Genes? A Discussion Document on the Storage, Protection and Use of Personal Genetic Information. URL (consulted February 2009): http://www.hgc.gov.uk/UploadDocs/DocPub/Document/ business_consultations2maintext.pdf

HGC (2001) Public Attitudes to Human Genetic Information: People's Panel Quantitative Study Conducted for the Human Genetics Commission. March, URL (consulted February 2009): http://www.hgc.gov.uk/UploadDocs/ DocPub/Document/morigeneticattitudes.pdf

HGC (2006) Making Babies: Reproductive Decisions and Genetic Technologies. URL (consulted February 2009): http://www.hgc.gov.uk/Client/document.asp?DocId=112\&CAtegoryId=8

HGC (2008) "What is the Consultative Panel?," URL (consulted February 2009): http://www.hgc.gov.uk/Client/ Content.asp?ContentId=375

Irwin, A. (2001) "Constructing the Scientific Citizen: Science and Democracy in the Biosciences," Public Understanding of Science 10(1): 1-18.

Irwin, A. (2006) "The Politics of Talk: Coming to Terms with the 'New' Scientific Governance," Social Studies of Science 63(2): 299-320.

Irwin, A. and Michael, M. (2003) Science, Social Theory and Public Knowledge. Maidenhead: Open University Press.

Irwin, A. and Wynne, B. (1996) Misunderstanding Science? Cambridge: Cambridge University Press.

Jasanoff, S. (2003) "Technologies of Humility: Citizen Participation in Governing Science," Minerva 41(3): 223-44.

Lengwiler, M. (2008) "Participatory Approaches in Science and Technology: Historical Origins and Current Practices in Critical Perspective," Science, Technology, and Human Values 33(2): 186-200.

Levidow, L. (1998) "Democratizing Technology - or Technologizing Democracy? Regulating Agricultural Biotechnology in Europe," Technology in Society 20(2): 211-26.

Levidow, L. (2007) "European Public Participation as Risk Governance: Enhancing Democratic Accountability for Agbiotech Policy?," East Asian Science, Technology and Society: an International Journal (EASTS) 1(1): 19-51.

Levidow, L. and Carr, S. (1997) "How Biotechnology Regulation Sets a Risk/Ethics Boundary," Agriculture and Human Values 14(6): 29-43.

Levidow, L. and Marris, C. (2001) "Science and Governance in Europe: Lessons from the Case of Agricultural Biotechnology," Science and Public Policy 28(5): 345-60.

Lezaun, J. and Soneryd, L. (2007) "Consulting Citizens: Technologies of Elicitation and the Mobility of Publics," Public Understanding of Science 16(3): 279-97.

Loeber, A. and Haila, Y. (2009) "Analogue Models and Dynamic Generalization - the Paganini Experience," Paper prepared for presentation at the 4th Interpretive Policy Analysis Conference, "Discourse and Power in Critical Policy Studies," Kassel, 25-7 June.

Mansbridge, J. (1990) "Feminism and Democracy," The American Prospect 21 March, URL (consulted February 2009): http://www.prospect.org/cs/author?id=144

Marres, N. (2007) "The Issues Deserve More Credit: Pragmatist Contributions to the Study of Public Involvement in Controversy," Social Studies of Science 37(5): 759-80.

Michael, M. (2009) "Publics Performing Publics: Of PiGs, PiPs and Politics," Public Understanding of Science 18(5): 617-31. 
Moore, A. (forthcoming) "Public Bioethics and Public Engagement: The Politics of 'Proper Talk," Public Understanding of Science.

Mouffe, C. (2006) On the Political. London and New York: Routledge.

Nowotny, H., Gisler, P., Guggenheim, M., Pohl, C. and Maranta, A. (2004) Imaginierte Laien. Die Macht der Vorstellung in wissenschaftlichen Expertisen. Weilerswist: Velbrueck Wissenschaft.

Pestre, D. (2008) "Challenges for the Democratic Management of Technoscience: Governance, Participation and the Political Today," Science as Culture 17(2): 101-19.

Reardon, J. (2007) "Democratic Mis-haps: The Problem of Democratization in a Time of Biopolitics," BioSocieties 2(2): 239-56.

Reynolds, L. and Szerszynski, B., with Volakakis, Y. and Kousis, M. (2007) GM-Food: The Role of Participation in a Techno-Scientific Controversy. Final Work Package Report for "Participatory Governance and Institutional Innovation" [PAGANINI], funded by the 6th EU FRP (Contract No. CIT2-CT-2004-505791). URL (consulted February 2009): http://www.univie.ac.at/LSG/paganini/output.htm

Rowe, G. and Frewer, L. J. (2004) "Evaluating Public-Participation Exercises: A Research Agenda," Science, Technology, and Human Values 29(4): 512-56.

Salter, B. and Jones, M. (2002) "Regulating Human Genetics: The Changing Politics of Biotechnology Governance in the European Union," Health, Risk and Society 4(3): 325-40.

Sanders, L. (1997) “Against Deliberation,” Political Theory 25: 347-76.

Sartori, G. (1978) "Anti-Elitism Revisited," Government and Opposition 13(1): 67-71.

Schicktanz, S. and Naumann, J. (2003) Bürgerkonferenz: Streitfall Gendiagnostik. Ein Modellprojekt der Bürgerbeteiligung am bioethischen Diskurs. Opladen: Leske und Budrich.

Schultz, S., Braun, K. and Griessler, E. (2007) The Governance of Genetic Testing: Non-Antagonistic Setting, "Authentic Publics" and Moments of Unease. Final Report of Work Package 3, Participatory Governance and Institutional Innovation [PAGANINI]. URL (consulted February 2009): http://www.univie.ac.at/LSG/paganini/output.htm

Sperling, S. (2007) "Knowledge Rites and the Right Not to Know," PoLAR: Political and Legal Anthropology Review 30(2): 269-87.

Stirling, A. (2008) “'Opening Up' and 'Closing Down': Power, Participation, and Pluralism in the Social Appraisal of Technology," Science, Technology, and Human Values 33(2): 262-94.

Waldschmidt, A., Klein, A. and Tamayo Korte, M. (2009) Das Wissen der Leute. Bioethik, Alltag und Macht im Internet. Wiesbaden: VS Verlag für Sozialwissenschaften.

Wynne, B. (2002) "Risk and Environment as Legitimatory Discourses of Technology: Reflexivity Inside Out?," Current Sociology 59(3): 459-77.

Wynne, B. (2005) 'Risk as Globalizing 'Democratic' Discourse? Framing Subjects and Citizens," in M. Leach, I. Scoones and B. Wynne (eds) Science and Citizens: Globalization and the Challenge of Engagement, pp. 66-82. London and New York: Zed Books.

Wynne, B. (2006) "Public Engagement as a Means of Restoring Public Trust in Science: Hitting the Tone but Missing the Music?," Community Genetics 9(3): 211-20.

Young, I. M. (2002) Inclusion and Democracy. Oxford: Oxford University Press.

\section{Authors}

Kathrin Braun is lecturer at the Centre for the Study of Bioscience, Biomedicine, Biotechnology and Society (BIOS) at the London School of Economics and Political Science. Correspondence: London School of Economics and Political Science, Houghton Street, London WC2A 2AE, UK; e-mail: k.braun1@1se.ac.uk

Susanne Schultz is a postdoctoral researcher at the University of Hanover. 